\title{
Kamu Personelinin Belirtilmiş Dindarlık Düzeyleri ile Görev Motivasyonları İlişkisi Üzerine Bir İnceleme
}

\author{
DOI: $10.26466 /$ opus.617372
}

\author{
Serdar Vural Uygun ${ }^{*}$ \\ * Dr. Öğr.Üyesi, Nevşehir HBV Üniversitesi, İ̈BF, Nevşehir/Türkiye \\ E-Posta: serdarvuraluygun@nevsehir.edu.tr ORCID: 0000-0001-6420-641X
}

Öz

Günümüzde, kamu yönetiminin esnek, hesap verebilir, etkili ve verimli biçimde yürütülmesinin gerekliliği genel kabul gören bir zorunluluk olarak belirmiş durumdadır. Bunun sağlanması için de kamu hizmetlerinin mümkün olan en yüksek kalite ve yeterlilikte sunulması gerekmektedir. İște bu nedenle, kamusal hizmetin yerine getirilmesini sağlayan kamu personelinin görevlerine yönelik motivasyon düzeyleri büyük önem taşımaktadır. Motivasyon konusunda oluşturulmuş teorilerin hepsinin odak noktasında, hangi yöntem ve araçlar kullanilırsa kullamılsın, çalışanın içsel tatmininin să̆lanması gereğinin bulunmakta olduğu görülmektedir. Bu durumda da kişinin içsel hayatın şekillendiren vicdan ve inanç kavramlarının etkisi söz konusu olmaktadır. Kişinin mensup olduğu inanç sistemini yaşamına uygulama düzeyi anlamında dindarlı, insan hayatın şekillendirme potansiyeli taşımaktadır. Çalışma hayatı da günlük hayatın önemli bir parçası olduğundan, dindarlı düzeyinin kişinin çalışma hayatındaki motivasyonuna etki etmesi mümkün görülmektedir. Çalışma ile motivasyon düzeyinin, dindarlı düzeyi ile bir ilişkisinin olup olmadığı, varsa bu ilişkinin kuvveti ve yönü belirlenmeye çalışılmıştır. Bu sayede kamu personel yönetimi özelinde kamu çalı̧anlarının motivasyonlarının artırlması yönlü çalışmalara katkı sunmak amaçlanmaktadır. Çalışma, Türkiye'de Nevş̧ehir şehrinde bulunan kamu kurumlarmdan örneklem seçilen kurumlarm personeline yönelik olarak, anket yöntemi ile yürütülmüştür. Araştırma sonucu elde edilen veriler SPSS istatistik programı ile analiz edilmiş ve dindarlı seviyesi ile göreve yönelik sahip olunan motivasyon derecesi arasında zayıf ancak pozitif yönlü bir ilişki bulunduğu belirlenmiştir.

Anahtar Kelimeler: Kamu Personel Yönetimi, Dindarlık, Görev Motivasyonu 


\title{
An Analysis on Relationship Between Stated Piety Level and Task Motivation of Public Personnel
}

\begin{abstract}
Today, the necessity of conducting public administration in a flexible, accountable, effective and efficient manner has emerged as a general requirement. For this reason, the motivation levels of the public personnel that fulfill the public service are important. In the focal point of all the theories about motivation, no matter what methods and tools are used, it is seen that there is a need to ensure the internal satisfaction of the employee. In this case, the concepts of conscience and belief, which shape the inner life of the person, are in question. Piety in the sense of the level of application of the belief system that the person belongs to to his life carries the potential to shape human life. Since the working life is an important part of daily life, it is possible that the level of piety may have an impact on the motivation of the person. The relationship between the level of motivation and the level of piety and the force and direction of this relationship were tried to be determined. In this way, it is aimed to increase the motivation of public employees in public personnel management. The study, samples from public institutions located in the city of Nevsehir in Turkey as to the personnel of selected institutions, was conducted with survey method. The data obtained from the study were analyzed with SPSS statistical program and it was determined that there was a positive but weak relationship between the level of piety and motivation.
\end{abstract}

Keywords: Public Personnel Management, Piety, Task motivation 


\section{Giriş}

Modern kamu yönetimi anlayışı, kamu hizmetlerinin etkin, etkili ve vatandaş odaklı biçimde yürütülmesini gerektirmektedir. Bu gerekliliğin sağlanabilmesi için temel şartlardan birisi de kamu hizmetlerinin vatandaşa sunumunu gerçekleştiren kamu personelinin, hizmeti yürütebilmek için mevzuatça belirlenmiş niteliklere sahip, bilinçli ve görevine motive durumda olması ile gerçekleşebileceği açıktır. Kamu personeli, motivasyonu yüksek düzeyde olduğunda, sunduğu hizmeti çok daha verimli ve etkili biçimde yürütülmesini sağlayacaktır. Çalışanların göreve yönelik motivasyonlarının sağlanması konusundaki teori ve çalışmalar incelendiğinde ise hangi yöntem uygulanırsa uygulansın bu konudaki asıl ve ortak belirleyicinin çalışanın psikolojik tatmin düzeyi olduğu görülmektedir.

Motivasyonun, bu durum dikkate alındığında, çalışanın inanç dünyası ile doğrudan ilgili olduğu söylenebilir. Çalışanın inanç durumu ve düzeyinin bir diğer ifadeyle dindarlık düzeyinin ise kişisel hayatın gerek uygulamada ve gerekse manevi olarak şekillenmesinde başat etkileyicilerinden biri olduğu düşünülmektedir. Çalışma hayatı, kişisel hayatın en önemli parçalarından birini oluşturduğundan, dindarlık düzeyinin personelin çalışma performansı, isteği, gayreti ve enerjisi yani motivasyonu üzerinde yapabileceği etkiyi incelemek önemli görülmüştür.

Yapılan kamu yönetimi literatür taramasında, söz konusu iki değişkenin birlikte ve özel olarak incelendiği bir çalışmaya rastlanılmamıştır. Bu itibarla konjonkturel olarak üzerinde oldukça konuşulan bir olgu durumundaki dindarlığın, kamu personelinin motivasyon düzeyine ve dolayısıyla kamu hizmetlerinin yürütülmesine yaptığı etki düzeyi ve yönünü incelemenin, kamu yönetiminin verimliliği ve motivasyon konusundaki çalışmalara katkı sağlayabileceği düşünülmektedir.

Çalışmanın ilk bölümünde din ve dindarlık kavramları tanımlanmaya çalışılmış, ikinci bölümünde motivasyon kavramı ve bu konudaki çalışmalar incelenmiştir. Çalışmanın üçüncü bölümünde ise, dindarlık düzeyi ile görev motivasyonu arasındaki ilişkinin varlık durumunu, seviyesini ve yönünü belirlemek amaçlı yürütülen alan araştırmasının SPSS 18.0 programı ile analiz edilmiş sonuçları sunulmuştur. Son bölüm ise konu ile ilgili genel bir değerlendirmeyi içermektedir. 


\section{Din ve Dindarlık}

Din, etimolojik olarak, yol, kanun, hukuk, hüküm gibi anlamlar taşımakla birlikte, kavramsal olarak, mensubu olan insanlara, yaşamlarını şekillendirmeye yönelik olarak, belirli kurallar, emirler ve yasaklar getiren, talimatlar veren, kimi zaman statik kimi zaman da dinamik karakterli bir yaşam tarzı belirleyen, davranış biçimleri öngören öğretiler bütünü (Gündüz, 1998, s.34; Çalışkan, 2002, s.55) olarak tanımlanabilir.

Dindar ise, mensubu olduğu dinin emir, yasak ve yönlendirmelerine uyarak bunların gereklerini yerine getiren kimse demektir. Yine dindar, kabul ettiği dinin emir, yasak, pratik ve sembollerini benimseyerek bunları tutum ve davranışlarına yansıtan kişidir (Ayverdi, 2005, s.726; Kurt, 2009, s.5). Bu itibarla dindar olarak tanımlanacak kişi, dini, yaşamının fonksiyonel bir göstergesi haline getirmektedir. Böylece kişinin kendi inanç alanı içerisindeki bireysel gerçeklik durumu hakkında bilgi edinilebilmektedir (Subaşı, 2014, s.37).

Araştırmalarda, "dindarlık" kavramının ise birçok farklı biçimde yapıldığı görülmektedir. Kişinin herhangi bir dine bağlı olması ve bu dinin emrettiklerini gayretle yerine getirme, bu dine ait inanç, ibadetlerle meşgul olma derecesi (Ayverdi, 2005, s.726; Kurt, 2009, s.6; Gündüz, 1998, s.38) olarak tarif edilebilen dindarlık, bir kişinin inandığı dinin günlük yaşamında kapladığı alanın büyüklüğünü, kişinin bu dine bağlanma derecesini ifade ettiği (Taş, 2006, s.177) söylenebilir. Marshall ise dindarlığı, dinsel kuralları takip etmek ve dinsel öğretilere inanmak (Marshall, 1999, s.156) biçiminde ifade etmektedir.

Dindarlık kavramının, Günay'ın belirttiği gibi, kutsal olanın ya da belli bir dinin belirli zaman ve şartlarda belli bir kişi veya grup ya da toplum tarafından yaşanması (Günay, 2002, s.8) biçiminde "yaşanma" odaklı tanımlanması da mümkündür.

Onay, insan ile yüce varlık arasında oluşan inanç bağı çerçevesinde yürüyen ilişkiler bütünü olan dinin bireyin hayatına yansıması (Onay, 2004, s.17), biçiminde dindarlığı tanımlar.

Johnstone, din kavramını, kendi üyeleri tarafından paylaşılan kutsal ve aşkın güçlere inanmaya odaklanmış inançlar ve uygulamalar bütünü olarak tanımladıktan sonra, belirli aşkın ve kutsal şeylere inanan, bu inançlar 
doğrultusunda belirli aktiviteler yapan ve dinî bir grup üyesi olan kişiye dindar; bu üyelerin yaptıkları uygulamaların hayatındaki yoğunluk derecesine ise dindarlik demektedir (Johnstone, 1992, s.58-59).

Psikolojik açıdan bakıldığında ise dindarlığın, Freud tarafından "hastalıklı bir ruh hali"; Jung, Allport ve Maslow tarafından ise "ruh sağlığı için olumlu bir unsur" olarak ifade edildiği görülmektedir (Allport 2004, s.96; Hökelekli, 2010, s.71). Bu durumda dindarlık konusunda da benzer yönlü, farklı görüşlerin olduğu görülmektedir.

Nitekim Hökelekli, dindarlık hakkında, onun belirli, standart bir biçimi olmadığını, bireylerin farklı karakterde olmasının, kişisel bir din yöneliminden bile bahsedilebileceğini vurgulamıştır. (Hökelekli, 2010, s.81) Allport, dünya üzerinde dindar eğilimdeki insan sayısı kadar dinsel deneyim türü olduğunu (Allport, 2004, s.46) ifade etmiş, benzer biçimde Spilka ve Hood da her bir dinin tek bir yolu bulunmasına karşın, dindarlığın yüzlerce olası yolu olduğundan belirtmişlerdir (Spilka ve Hood vd., 1985, s.7).

Çalışmamızda dindarlık kavramı, din farklılı̆̆ gözetilmeden, çalışanların dindarlık düzeyleri ölçülmeye çalışılacaktır. Yeryüzündeki tüm dinlerin ortak değerlerinin (doğru olanı konuşma, başkasının hakkına saygılı olma, hirsızlık yapmama, ibadet etme, ölümden sonraki hayata inanma ve Yaratıcıya hesap verme gibi) bulunduğu bir gerçektir. Bu değerlerin hayata yön verme düzeyi yani dindarlık seviyesi arttıkça, insan belirli davranışlara zorlamakta ve tercihlerini söz konusu değerlere göre belirlemektedir. İnsan hayatının önemli bir bölümünü oluşturan iş yaşamının da bu değerlerin etki alanı içerisinde kalacağı açıktır. İşte bu çalışmayla, çalışanın dindarlık düzeyinin onun mesleki ve görevsel tatmin düzeyine ve görevine yönelik davranışlarına etkisini belirlemek amaçlanmaktadır.

\section{Motivasyon}

Latince "movere" (hamle, hareket) kelimesinden türetildiği ifade edilen (Baysal ve Tekarslan, 1998, s.101) motivasyon kavramını; kişiyi harekete geçirerek, bu hareketin olumlu olarak devamını sağlayan gayretler bütünü (Eren, 2015, s.498; Şimşek vd., 2010, s.177), kişinin belirli bir amaca ulaşmak için kendi isteği ile harekete başlaması (Koçel, 2013, s.619); ihtiyaçlarını karşılamaya yönelik harekete başlamak için etkilenme süreci (Vural ve Coşkun, 2009, s.115); kişiyi karşılaştığ1 durumlara göre belirli davranışları 
göstermeye yönelten etkenler (Fındıkçı, 2009, s.371); kişileri belirli bir amaç doğrultusunda harekete yönlendirmek için yürütülen çabalar bütünü (Ceylan ve Anbar, 2014, s.350); çalışanın, örgütsel amaçları gerçekleştirmek için harekete geçmesini saylamaya yönelik çabalar (Başaran, 2008, s.90); başlangiç, istikamet, şiddet ve etki etme süresi kişiden kişiye değişen ve kişiyi belirli bir davranışı yapmaya yönlendiren iç veya dış güç (Pinder, 1998); bir davranışın hevesli biçimde yapılması esnasında hissettiğimiz duygular bütünü (Bentley, 2000, s.179); kişiye istenilen belirli bir davranışı yapması için gerekli isteği verme süreci (Berkman v.d., 2007, s.293) veya çalışanların belirli kişisel ve örgütsel hedeflere ulaşmasını amaçlayan itici güç (Katı ve Düşükcan, 2017, s.3) biçimlerinde tanımlamak mümkündür. Bütün bu tanımların ortak yönleri dikkate alındığında, motivasyonun, bireyi belirli davranışa ikna ve teşvik ederek yöneltmek biçiminde ifade edilebileceği söylenebilir.

Motivasyonun, içsel ve dişsal biçiminde belirlenebilecek iki temel etkileyici grubu tarafından gerçekleştiği söylenebilir (Koçel, 2013, s.622; Akbaba, 2006, s.344; Newstrom ve Davis, 2002, s.109):

Dışsal Motivasyon; Faaliyete/işe/göreve doğrudan bağlı olmayan dışsal motivasyon, kişinin "elde edeceği şey" ile bağlantılıdır. Farklı nitelikteki ödüller ve cezalar gibi kişiye yönelik kendi dışından yönelen etkileyicilerden meydana gelir (Cerasoli vd., 2014, s.5). Dışsal motivasyonun gerçekleşmesi, kişinin kendisine yöneltilen etkileyiciyi yorumlama biçimi ile doğrudan bağlantılıdır (Grant vd., 2011). Bu nedenle aynı etkileyici, farklı kişilerde farklı yönde ve şiddette tepkiler verilmesine neden olabilmektedir (Latham ve Locke, 1992, s.197).

İçsel Motivasyon; Bireyin tamamen ve dışarıdan herhangi bir etkileyici olmadan harekete geçmesini sağlayan unsurlar, içsel motivasyon kapsamında değerlendirilmektedir (Grant vd., 2011). Aynı zamanda içsel motivasyon, kişiye özel ve tatmin edilmeyi bekleyen ihtiyaçları gidermek için kişide oluşan istek, ilgi ve merak gibi etkilerle kendisini gösteren tepkiler olarak da tanımlanabilir (Batmaz ve Gürer, 2016, s.481; Ağca ve Ertan, 2008, s.140). Sorumluluk üstlenmek, bağımsız hareket etmek, kendisini ispatlamak ve saygınlık kazanmak gibi ihtiyaçlar, içsel motivasyon ile ilgilidir. Bu motivasyon unsurları daha çok, kişinin yaptığı iş dışında başka herhangi bir güdüleyici ile motive edilmediği durumlarda etkili olmaktadırlar (Özdaşlı ve Akman, 2012, s.75). 
Çalışanlar üzerindeki etkisinin yüksekliği, motivasyonun yönetsel açıdan büyük öneme sahip olmasını sağlamıştır. Motivasyon konusunda yürütülen çalışmalar ile ortaya konulan teorileri, "kapsam teorileri" ve "süreç teorileri" olmak üzere iki grupta incelemek mümkündür (Kanfer ve Chen, 2016; Eren, 2015; Gröpel ve Kehr, 2014; Koçel, 2013; Chen ve Mathieu, 2008).

Kapsam teorileri, motive edici faktörlere odaklanan çalışmalardan oluşmaktadır (Aşan, 2001, s. 226-227). Bu teori grubu içerisinde, Maslow'un, kişilerin motivasyonun onların belirli bir hiyerarşiye sahip ihtiyaç seviyelerinden hangisinin içerisinde bulunduğuna bağlı olduğunu belirttiğ İhtiyaçlar Hiyerarşisi Kuramı; Alderfer'in, motivasyonu sağlayan ve tatmin edilmesi gereken kişisel ihtiyaçları gelişme, ilişki kurma ve varolma biçiminde üç gruba ayırarak incelediği ERG Yaklaşımı; Herzberg'in, motivasyonun dışsal unsurların "hijyen etmenler" olarak tanımladığ içsel unsurların etki durumuna doğrudan etki ettiğini belirttiği Herzberg Modeli; McClelland'ın, kişisel ihtiyaçları "başarı, bağlılık ve güçlülük" olarak belirleyen ve kişinin dışşsal etkenlerden çok içsel etkenler ile ile motive olduğunu ileri sürdüğü Başarı Güdüsü adlı teorisi ve Locke'un, çalışanın motivasyon derecesinin örgütün amaçları ile kendi amaçları arasındaki örtüşme derecesine göre belirlendiğini vurguladığı Bireysel Amaçlar ve İş Başarısı adlı teorisi bulunmaktadır.

Motivasyonu belirli bir dönem için değil, sürekli devam eden bir süreç olarak gören ve kişisel farklılıkların motivasyon süreci konusundaki etkisini öne çıkaran (Eren, 2015, s.532; Koçel, 2013, s.622) "süreç teorileri" kapsamında ise; Vroom'un, motivasyonun kişiden beklenilen davranışın onların bekledikleri şekilde ödüllendirilmesi durumunda ortaya çıkacağını ifade ettiği Ümit (Beklenti) Kuramı; Lawler ve Porter'ın, davranışa yönelik ödüllendirmenin ancak adil biçimde yapılması şartıyla motivasyona olumlu etki edebileceğini savundukları Geliştirilmiş Ümit Kuramı; Adams'ın, ödüllendirmedeki eşitlik ve denge unsurlarının doğru uygulanması ile çalışanlar üzerinde belirleyici olabileceğini vurguladıkları Ödül Eşitliği Kurami; Cranny ve Smith'in örgütsel başarının doğru yönlü motive edilmiş çalışanların kişisel çabaları ile sağlanacağına vurgu yaptıkları Basitleştirilmiş Süreç Modeli ile Pavlov ve Skinner'ın olumlu ve istenilen davranışların desteklenmesinin ve olumsuz, istenmeyen davranışlara da tepki gösterilmesinin motivasyonu oluşması için gerek şart olduğunu ileri sürdükleri Şartlandırma (Pekiştirme) Kuramı, yer almaktadırlar. 
Her iki teori grubu da motivasyon sağlayıcı unsurlar bakımından incelendiğinde, motivasyonunu sağlamak için çalışanlara yönelik yönetimin kullanabileceği araçlar ise etkileyicinin hedefi, yönü, amacı ve biçimi dikkate alınarak şu şekilde sınıflandırılabilmektedir (Batmaz ve Gürer, 2016, s.481; Kanfer ve Chen, 2016, s.9; Rawolle vd., 2016; Eren, 2015, s.516; Cihangiroğlu ve Uzuntarla, 2015, s.348; Barutçu ve Sezgin, 2012, s.91; Şenel vd., 2012, s.5; Ergül, 2005, s.72; Ölçer, 2005, s.3; Akçakaya, 2004, s.211).

Ekonomik Araçlar: Bu tür araçlar, çalışanların maddi ihtiyaçlarının tatminine yönelik kullanılan motivasyon araçlarıdır. Örgütün yönetimi tarafından, ücrette artış sağlanması (zam yapma, prim verme, kâra ortak etme, hisse verme vb.), maddi değeri bulunan ödüllerin verilmesi, yemek ve kira yardımı, ulaşım imkanı/katkısı sağlama gibi çalışanın ekonomik imkanlarını artırmaya yönelik uygulamalar, ekonomik yönlü motivasyon araçları olarak tercih edilebilmektedirler.

Psiko-sosyal Araçlar: Çalışanın psikolojik açıdan tatmin edilmesine ve sosyal ilişkilerine katkı sağlayarak motive olmasını amaçlayan motivasyon araçlarıdır. Çalışana yürüttüğü görevde inisiyatif kullanma yetkisi verilmesi, çalışanın kişisel sorun ve sıkıntılarına yönelik duyarlı olunması, çalışma arkadaşları ile üstleri tarafından takdir ve onore edilmesi, yönetsel kararlar ve faaliyetler yönelik önerilerinin dikkate alınması, mesleki statü kazandırılması ile çalışanlara yönelik sosyal faaliyetler (personel tanışma toplantıları, personelin aileleri ile gerçekleşen etkinlikler, geziler vb.) düzenlenmesi, bu grup kapsamında kullanılan araçlar arasındadır.

Yönetsel ve Örgütsel Araçlar: Örgütte uygulanan yönetim anlayışı ve oluşturulan örgüt kültürü sayesinde çalışanlara uyumlu, güvenli ve verimli çalışabilecekleri bir iş ortamı oluşturulması ile çalışanın kariyerini geliştirmeye ve bu kapsamdaki belirsizliklerini ortadan kaldırmaya yönelik uygulamalar, bu motivasyon araç grubu içerisinde değerlendirilmektedir. Örgütte iş güvenliğinin etkin biçimde sağlanması, işyerinin fiziksel çalışma koşullarının düzeltilmesi, işyerinde yapıcı bir rekabet ortamının oluşturulması, iş rotasyonu ve zenginleştirmesi yapılması, güncel görev gereksinimleri ile ilgili hizmet içi eğitimler verilmesi, kariyer danışmanlığı desteğinin 
sağlanması, standart kurallı, objektif ve adaletli bir disiplin sistemi oluşturulması ile etkili ve kesintisiz işleyen bir yönetsel iletişim sistemi kurulması, bu grup motivasyon araçlarına örnek olarak verilebilir.

\section{Kamu Kurum Personelinin Belirttikleri Dindarlık Düzeyleri İle Görev Motivasyonları Arasındaki İlişkiye Yönelik Elde Edilen Verilerin Değerlendirilmesi}

Çalışmanın bu bölümünde Nevşehir ölçeğinde kamu kurumlarında çalışanlar üzerinde yürütülen ve kişisel, belirtilen dindarlık düzeyinin görev ve çalışma motivasyonu üzerindeki etki durumu ve düzeyini belirlemeye yönelik anket çalışması neticesinde elde edilen bulgular değerlendirilmektedir. Ankete katılanların kişisel özelikleri belirtildikten sonra elde edilen veriler tablolar halinde ortaya konularak yorumlanmaktadır.

\section{Araştırmanın Amacı, Kapsamı Ve Yöntemi}

Araştırma, kamu kurum personelinin dindarlık düzeylerinin, göreve yönelik motivasyonlarına etki durumunu ve seviyesini belirlemek amacıyla, Nevşehir il merkezinde bulunan ve farklı faaliyet alanlarında kamu hizmeti veren Sağlık İl Müdürlügü, Gençlik ve Spor İl Müdürlüğü, Nevşehir Belediyesi ve İl Jandarma Komutanlığı bünyesinde çalışan, il merkezinde görevli toplam 291 personel üzerinde yürütülmüştür. Araştırmada anket yöntemi kullanılmıştır. Hazırlanan anket, bu kurumlarda memur kadrosunda görevli toplam 411 kadrolu çalışandan, anketi cevaplamayı kabul eden 291 personel ile yüz yüze görüşülerek uygulanmıştır. Anketin seçilen örneklem için uygulanma oranı \%70,8 olmuş, değerlendirme aşamasına geçilmiştir.

Araştırma için hazırlanan anket, üç bölümden oluşmaktadır. Birinci bölüm katılımcıların genel özelliklerini belirlemek amaçlı olarak hazırlanmış ve 2 adet sorudan oluşmuştur. Bu bölümdeki sorular, anket katılımcılarının dindarlık gibi hassas bir konudaki soruları daha gerçekçi cevaplamaları amaçlanarak çok genel iki soru ile sınırlı tutulmuştur. İkinci bölüm kurum çalışanının görev ve çalışma motivasyonu düzeyini belirlemeye yönelik 10 adet; üçüncü bölüm, çalışanın dindarlık düzeylerini belirlemeye yönelik 18 adet, 5’li likert ölçeği ile hazırlanmış sorudan oluşmaktadır. 
Dindarlık, dini yönelim ve dini bilinç düzeylerini ölçmek üzere, Brown (1962), Faulkner ve DeJong (1966), King ve Hunt (1969),Mutlu (1989), Uysal (1995), Coştu (2009) ve Seyhan (2015) tarafından geliştirilen ölçekler incelenip çalışma konusu doğrultusunda revize edilerek "dindarlık düzeyi anketi"; Allen ve Meyer (1990), İncir (1990), Kuvaas (2006) ile Batmaz ve Gürer (2016) 'in çalışanların motivasyon seviyelerinin belirlenmesi amaçlı hazırlamış oldukları ölçekler incelenip revize edilerek "görev motivasyonu düzeyi anketi", oluşturulmuştur.

Araştırma anketinin SPSS 18.0 programı kullanılarak hesaplanan ölçek güvenilirlik testi sonuçları aşağıda belirtilmiştir:

Tablo 1. Ölçek Güvenilirlik Testi Sonuçları

\begin{tabular}{lcc}
\hline & Cronbach's Alpha Değeri & Ölçek Madde Sayısı \\
\hline Dindarlık Düzeyi Ölçeği & $\mathbf{9 5 3}$ & 18 \\
Görev Motivasyonu Ölçeği & $\mathbf{8 6 3}$ & 10 \\
Birleştirilmiş Anket Ölçeği &, 928 & 28 \\
\hline
\end{tabular}

Ölçeklere uygulanan Cronbach's Alpha Testi; Dindarlık Düzeyi Ölçeğinin güvenilirliğini, “.953” olarak ve Görev Motivasyon Düzeyi Ölçeğinin güvenilirliğini ise ".863" olarak hesaplamıştır. Belirlenen bu değerlerin uygulanan her iki ölçeğin de "yüksek güvenilirlikte" (Büyüköztürk, 2007) olduğunu gösterdiği söylenebilir.

Araştırmada model olarak, bağımsız değişken "dindarlık düzeyi"; bağımlı değişken "motivasyon düzeyi" olarak öngörülmüştür. Araştırmanın "H: Kurum çalışanlarının dindarlık arttıkça kurum çalışanlarının görev motivasyon düzeyleri artmaktadır." ifadeli hipotezi, SPSS P.18 programı ile çalıştırılan korelasyon analizi ve regresyon analizi ile test edilmiştir.

\section{Araştırma Bulgularının Değerlendirilmesi}

Bu kısımda, araştırma kapsamında hazırlanarak yürütülen anket uygulamasına katılan personelin demografik genel özellikleri ile çalışmanın belirtilen hipotezinin sınanmasına (personelin kendisi için ifade ettiği dindarlık seviyeleri ile görevlerine yönelik motivasyon seviyeleri arasındaki olası ilişkinin varlığı, yönü ve derecesi) yönelik elde edilen bulgular açıklanmaya çalışılmaktadır. 


\section{Katılımcıların Demografik Özellikleri}

Araştırma anketinin uygulandığı katılımc kurum personelinin demografik özellikleri ilgili hesaplanan frekans ve yüzdelik dağılımlar, Tablo 2'de gösterilmektedir. Anket katılımcısı personelin özellikle dindarlık konusunda daha rahat ve gerçekçi cevaplar vermelerini sağlamak amacı ile demografik sorular, sadece cinsiyet ve memuriyet süresi olarak yöneltilmiştir.

Tablo 2. Katılımcıların Demografik Özelikleri

\begin{tabular}{lcclcc}
\hline Cinsiyet & $\mathrm{f}$ & $\%$ & Memuriyet Süresi & $\mathrm{f}$ & $\%$ \\
\hline Kadın & 107 & 36,8 & $\mathbf{1 - 5}$ yıl & 67 & 23 \\
Erkek & 184 & 63,2 & $\mathbf{6 - 1 0}$ yıl & 69 & 23,7 \\
& & & $\mathbf{1 1 - 1 5}$ yıl & 49 & 16,8 \\
& & & $\mathbf{1 6}$ yıl ve üzeri & 106 & 36,4 \\
Toplam & 291 & 100 & Toplam & 291 & 100 \\
\hline
\end{tabular}

Tablo 2'de görüldüğü gibi ankete katılanların \%36,8'i kadın, \%63,2'Si erkektir. Katılımclar, \%23 oranında 1-5 yıl aralığında memuriyet süresi olan ve görevlerine görece yeni başlamış personelden oluşurken, \%23,7'si 6-10 yıl aralığında; \%16,8'i 11-15 yıl aralığında ve \%36,4'ü de 16 yıl ve üzerinde memuriyet süreleri olduklarını beyan etmişlerdir.

\section{Araştırma Bulgularının Analizi}

Elde edilen bulgular dindarlık düzeyi ve çalışanların motivasyon seviyeleri şeklinde iki başlık altında analiz edilmektedir.

\section{Dindarlık Düzeyi:}

Dindarlık düzeyini tespit amaciyla hazırlanan sorulara verilen yantlar analiz edildiğinde; örneklem kurumların katılımcı çalışanlarının \%91,4'ünün (\%67,7 kesinlikle, \%22,7 büyük ölçüde) mensubu oldukları dinin kendileri için vazgeçilmez olduğunu ifade ettikleri görülmektedir. Kurumların çalışanları, $\% 47,1$ oranında dinlerinin emrettiği günlük ibadetleri düzenli şekilde yaptıklarını belirtmektedirler. Dini toplulukları maddi-manevi olarak desteklediklerini söyleyenler ise sadece $\% 18,9$ oranındadır. Allah'ın varlığını 
hayatında hissettiğini söyleyenlerin oran, \%93,5 olup, dinin vazgeçilmezlik oranı ile örtüssmektedir.

Katılımcılardan $\% 57,4^{\prime} \ddot{u}$ her gün dua ettiklerini belirtirken, $\% 30$ 'u din hakkında kitaplar okuduklarını beyan etmektedirler. Tüm hayatlarını mensup oldukları dine göre düzenleyenlerin oranı \%44,3 (\%11,7 kesinlikle, \%32,6 büyük ölçüde)'tür. Dinin vazgeçilmezlik oranı ile hayatını dine göre düzenleme oranı arasındaki büyük fark, dinin manevi boyutunun uygulamada fazla karşılık bulamadığını göstermesi bakımından dikkat çekicidir. Nitekim Allah'ın sürekli kendisini izlediğini düşünerek yaşadığını belirtenlerin oranı olan \% 76,6 ile inancının hayatına anlam ve amaç kattığını belirtenlerin oranı olan $\% 75,9$ 'un örtüşmesi de uygulamada olmasa bile, din ve inancın manevi olarak tatmin edici özelliğinin katılımcılar tarafından kabul edildiğini göstermektedir.

Çalışma arkadaşlarını din kurallarına uyma konusunda yönlendirmeye çalışanlar, \%29,3 gibi görece düşük bir oranda iken, aynı konuda ailesini yönlendirdiklerini belirtenlerin oran ise $\% 57,3$ oranındadır. Bu durumun, katılımclların din konusunda ailelerine yönelik hassasiyetini gösterdiği söylenebilir. İnanç değerlerinin ve düşüncelerinin asla değiştirilemeyeceğini belirtenlerin oranı $\% 73,9^{\prime}$ dur. Bu oran, dindarlığın dogmatik yönünün ne denli yüksek olduğunu göstermektedir.

Dinin emirlerine göre davranmadığı zaman huzursuz olan kişi sayısı \%70,8 oranında iken, örtüşen biçimde peygamberi kendisine örnek alanların oran \%71,1'dir. Yine uygulamaya dönük farklılık olarak peygamberin yaptığı bütün ibadetleri yapmaya çalışanların oranı ise peygamberi örnek aldığını belirtenlerin oranından çok daha az olan \%59 oranındadır. Farz ibadetlerin yanında düzenli olarak nafile ibadet yaparım diyenler sadece \%34'tür. Peygamberin yaptığı farz dışı ibadetler, nafile ibadetler olarak belirtildiğinden, uygulamaya yönelik büyük fark burada da görülmektedir.

Kadere inandığını ve bunu kabullendiğini belirtenlerin oranı ise oldukça yüksek olarak, \%91,1'dir. Bu oranın, Allah'ın varlığını hayatında hissedenlerin oranı $(\% 93,5)$ ile örtüştüğü görülmektedir.

\section{Görev Motivasyonu Seviyesi:}

Araştırmanın yürütüldüğü kurumların personelinin mevcut görev motivasyonu düzeylerinin ölçülmesine yönelik sorulara verilen cevaplar analiz 
edildiğinde; \%74,2 oranında çalışanın, kendi başarısını amirinin başarısı ile özdeşleştirdiği, \%15,5'lik bir kesimin ise bu iki unsur arasında hiçbir şekilde özdeşleştirme yapmadığı belirlenmiştir. Personelin \%88,7 oranlı kesimi, kurumunun başarısı için çalışmaktan mutlu olduklarını ifade etmektedirler. Olumsuz beyanda bulunan \%11.3'lük kesim ile amirinin başarısı ile kendi başarısını özdeşleştirmeyen \%15,5'lik kesim ile oransal olarak birbirine yakın olduğu görülmektedir. Çalıştığı kurum yönünden görev motivasyonu yüksek düzeyli olmasına rağmen amirleri ile sorun yaşayan personelin bu durumun nedeni olduğu ifade edilebilir.

Sorumlu oldukları görevlerden memnun oldukların ifade eden personel oranı \%68,4 iken, yaptığ işin kurum açısından anlamlı olduğunu düşünenlerin \%89 gibi görece yüksek oranda olması, \%20,6 oranında personelin yaptığı işi ve tabi kendisini çalıştığı kurum açısından oldukça önemli olarak görmesine rağmen görev bakımından monotonluk içerisinde bulunduğunu belirtebilir.

Nitekim personelin sadece $\% 76,7$ gibi, yaptığı işi anlamlı bulanlara oranla görece düşük oranlı bir kesiminin toplum içerisinde kurumundan ve işinden gururla bahsettiği görülmüş, ayrıca çalıştı̆̆ birimde mutlu olduğunu ifade edenlerin oranı da yine görece düşük biçimde $\% 74,2$ olmuştur. Bu iki kesimin oransal olarak birbiriyle örtüşmesi ise işiyle gurur duyma durumu ile ve işinde mutlu olma durumunun birbiriyle oldukça yakın biçimdeki ilişkisini ortaya koymaktadır. Yine bu oransal örtüşme, çalışanların belirli bir kesiminin $(\% 20,6)$ yaşadığı düşünülen göreve yönelik monotonluk hissinin varlığını desteklemekte olduğunu söylemek te mümkün görülmektedir..

Sabah işe huzurlu biçimde geldiğini belirtenlerin oranı \%72,9 iken akşam evine dönerken huzurlu hissettiğini belirtenlerin oran ise $\% 69,8$ olarak belirlenmiştir. Oranların birbirine yakınlığının anketin uygulandığ 1 kurumlarda önemli seviyede huzurlu bir çalışma ortamının varlığını göstermesi açısından anlamlı olduğu ifade edilebilir.

Çalışma arkadaşlarıyla iyi anlaştıklarını ve onların kendilerini desteklediğini ifade eden personel oranının \%93,1 gibi görece yüksek olması ise çalışanların belirli bir kesiminin duyduğu huzursuzluğun (yaklaşı \%25) kurumundan ya da çalışma arkadaşlarından değil daha çok amir kaynaklı olduğunu düşünmeye imkan verdiği söylenebilir. 
Katılımcı personelin \%60,5'i kurumlarının, kendilerini, mesleki olarak geliştirmek için yaptıkları çalışmalar konusunda desteklediğini ifade etmektedirler. Katılımcı kurum yönetimlerinin personelin kurum ve amire yönelik memnuniyet düzeyleri de dikkate alındığında, bu konuda yeterli düzeyde görülmediği söylenebilir.

Dindarlık Düzeyi İle Görev Motivasyonu Seviyesi Arasındaki İlişkiye Yönelik Bulgular Ve Hipotezin Sinanmasi:

Araştırma kapsamında hazırlanarak yürütülen anket uygulaması neticesinde elde edilen veriler, SPSS 18.0 programında incelenmiş ve araştırmanın hipotezi olarak ortaya konulan "H: Kurum çalışanlarının dindarlık düzeyleri arttıkça görev motivasyon düzeyleri artmaktadır." ifadesinin doğrulanma durumunu tespit etmek için "Çalışanların Dindarlık Düzeyleri" ile "Görev Motivasyon Düzeyleri" “ arasındaki regresyon sonucu için Anova F varyans analizi; korelasyon sonucu için Pearson Correlation (r) testi çalıştırılmıştır. Bu testlerden elde edilen sonuçlar ve yorumları aşağıdaki tablolarda ifade edilmeye çalışılmıştır.

Tablo 3. Çalışanların Dindarlık Düzeyi İle Görev Motivasyonu Arasındaki İlişki Durumu Ve Yönü, Anova F Varyans Analizi

\begin{tabular}{lccccc}
\hline Model & Sum of Squares & df & Mean Square & F & p \\
\hline Regression & 525,019 & 1 & 525,019 & 11,671 &, $001^{a}$ \\
Residual & 13000,142 & 289 & 44,983 & & \\
Total & 13525,162 & 290 & & & \\
\hline
\end{tabular}

Test sonucu tespit edilen $\mathrm{p}$ değerinin (.001), $\mathrm{p}<0.05$ olması, kurum personelinin, verdikleri cevaplar neticesinde ölçülen dindarlık düzeyleri ile yürüttükleri görevlere yönelik sahip olduklarını belirttikleri ölçülen motivasyon düzeyleri arasında pozitif yönlü bir ilişki olduğunu göstermektedir.

Tablo 4. Çalışanların Dindarlık Düzeyi İle Görev Motivasyonu Arasındaki İlişki, Korelasyon Testi

\begin{tabular}{llcc}
\hline & & Vizyoner Liderlik & Görev Motivasyonu \\
\hline \multirow{3}{*}{ Dindarlı } & Pearson Correlation $(r)$ & 1 &, $197^{* *}$ \\
Düzeyi & Sig. (2-tailed) $(p)$ & &, 001 \\
\hline \multirow{3}{*}{ Görev Motivasyonu } & $N$ & 291 & 291 \\
& Pearson Correlation $(r)$ &, $197^{* *}$ & 1 \\
& Sig. (2-tailed) $(p)$ &, 001 & \\
& $N$ & 291 & 291 \\
\hline
\end{tabular}


Korelasyon (r) testi neticesinde, personelin ölçülen dindarlık düzeyleri ile göreve yönelik motivasyon düzeyleri arasında doğru orantılı ve ",197" seviyesinde bir bağlantı bulunduğu tespit edilmiştir. Bu seviye, karşılaştırılan değişkenler arasında istatistiksel olarak "düşük düzeyde" bir ilişki olduğunu göstermektedir (Köklü vd., 2006). Buna göre personelin dindarlık düzeyindeki değişim, görev motivasyonu düzeyindeki değişimi, \%19,7 oranında açıklayabilmektedir.

Sonuç olarak, Tablo 3 ve Tablo 4'te belirtilen istatistiksel test sonuçları birlikte yorumlandığında ( $\mathrm{p}=, 001 ; \mathrm{r}=0,197)$, kurum personelinin cevapları doğrultusunda, ölçülen dindarlık düzeyleri ile görevlerine yönelik motivasyon düzeyleri arasında, \%19,7 gibi düşük bir oranda pozitif yönlü ve anlamlı bir ilişki olduğu ifade edilebilir. Bu itibarla "H: Kurum personelinin dindarlık düzeyleri arttıkça görev motivasyon düzeyleri artmaktadır." şeklinde ifade edilen araştırma hipotezi, kabul edilmiştir.

\section{Sonuç ve Değerlendirme}

Kamu hizmetlerinin kaliteli, anlamlı ve yeterli nitelikte yürütülebilmesi ile kamu kurum çalışanlarının sahip oldukları motivasyon düzeyi arasında önemli bir bağ olduğu rahatlıkla söylenebilir. Çünkü hizmeti yerine getirenler, kamu çalışanlarıdır ve bu itibarla onların görevlerine ve yaptığı işlere yönelik motive edilme/olma seviyeleri, hizmetin niteliğine doğrudan etki etmektedir.

Görevsel ve mesleki motivasyon konusundaki tüm teoriler incelendiğinde, kişisel görev motivasyonun sağlanabilmesi için temel belirleyicinin yine kişinin kendisi olduğu görülmektedir. Dış etkileyicilerin türü, şiddeti ve yönü ne olursa olsun, kişinin motive olmayı kabul etmesi ve buna yönlenmesi gerek şart durumundadır. Bu itibarla bütün motivasyon yöntemleri, çalışanı bu yönlü ikna etmek ve/veya yönlendirmek amacını gütmektedirler. İnsanın içsel, psikolojik ve manevi yönleri ile doğrudan ilişkisi olduğu rahatlıkla görülebilecek olan motivasyon olgusunun, bu yönü ile çalışanın inanç dünyası ile de bağlantılı olabileceğini düşünmek yanlış olmasa gerektir. İnanç seviyesi yani çalışmamızda kullanılan ifadesi ile dindarlık düzeyi ile motive edilme/olma düzeyi arasındaki ilişkiyi inceleme ihtiyacl, işte bu düşünceye dayanmaktadır. Buna göre kişisel yaşamın önemli etkileyici un- 
surlarından birisi olan dinin ve bu etkinin muhtemel derecesini gösteren dindarlığın, kişinin en büyük günlük yaşam bölümünü oluşturan iş yaşamına etki etmemesi mümkün görülmemektedir.

Bu itibarla kamu kurumu çalışanlarının dindarlık seviyelerinin görev motivasyonlarına yaptığı etki derecesi ve yönünü incelemeyi amaçladığımız araştırma neticesinde, dindarlık seviyesi ile çalışan motivasyon düzeyi arasında pozitif yönlü bir ilişki olduğu tespit edilmiştir.

Çalışanların, dindarlık düzeylerini belirlemek amaçlı sorulara yüksek oranda olumlu cevaplar verdikleri görülmektedir. Dinin, kendileri için vazgeçilmez olduğunu, Allah'ın varlığına inandıklarını, her gün dua ettiklerini, inançlarının hayatlarına anlam verdiğini ve ailelerini din kurallarına uyma yönünde yönlendirdiklerini belirtmektedirler.

Aynı şekilde katılımc kamu kurum çalışanlarının büyük çoğunluğu Allah'ın kendilerini sürekli izlediğini düşünmekte, Kaderin hayatların doğrudan etkilediğine inanmakta, peygamberlerinin hayatların örnek almakta, dinin emirlerine uymadıkları zaman huzursuz olduklarını ve inanç değerlerinin ve düşüncelerinin değiştirilemeyeceğini belirtmektedirler.

Bununla birlikte, çoğunluk, hayatını tamamen dinine göre düzenlemediğini, farz olarak ifade edilen dinin zorunlu ibadetleri ve yine nafile olarak ifade edilen isteğe bağlı ibadetleri düzenli olarak yapmadığını, dini toplulukları desteklemediğini, çalışma arkadaşlarını din konusunda yönlendirmediğini, dini kitaplar okumadıklarını ifade etmektedirler.

Bu durum, çoğunluk katılımcı için dinin varlığının psikolojik etkisi ile manevi anlamda vazgeçilmez görüldügüüü ve kavramsal anlayış olarak dindarlık konusunda tartışmaya kapalı ve dogmatik bir düşünsel yapıya sahip olunduğunu gösterebilmektedir. Nitekim dinin uygulanma ve günlük hayata ve çalışma hayatına entegre edilme durumların öğrenme amaçlı yöneltilen soruların görece oldukça düşük oranda kalması da dinin manevi boyutuyla katı biçimde benimsenmesine rağmen dindarlık kavramının uygulamaya yansıtılan bir nitelikte olmadığını ortaya koyduğu söylenebilir. Ayrıca din kitaplarının okunma oranının görece düşüklüğünün de, örneklem kapsamında, dindarlığın dinamik ve öğrenilip benimsenerek oluşmuş değil, dogmatik ve edilgen yapısını gösteren bir diğer unsur olduğu söylenebilir.

Görevlerine yönelik motivasyon durumları bakımından ise çalışanlar, motivasyon açısından en yüksek oranda; kurumun ve amirlerinin başarısı ile 
kendi başarılarını özdeşleştirmekte, yaptıkları işin anlamlı olduğunu, iş arkadaşları ile iyi anlaştıklarını ve onları desteklediklerini ve sabah işe gelirken huzurlu olduklarını ifade etmişlerdir.

Görevsel monotonluk sebepli açıklanabilecek biçimde, yerine getirdikleri görevlerin kendisini mutlu ettiğini belirten ve akşam eve dönerken huzurlu hissettiğini beyan eden çalışan oranlarının ise görece düşük olduğu görülmektedir. Benzer biçimde kendini geliştirme konusunda kurumundan yeterli desteği gördüklerini ifade edenler de motivasyon anketinin en düşük olumlu orana sahip grubunu oluşturmuşlardır. Kamu kurumlarının bu konuda çalışanlarını teşvik ederek desteklemeleri, gereken eğitsel, yönetsel ve kanuni düzenlemeleri gerçekleştirmek için çalışma yürütmeleri gerektiği söylenebilir.

Çalışanların yürüttükleri görevlerinin onların motivasyon düzeylerine etkisi açısından bakıldığında ise görevlerinin kendilerine verdiği motivasyon hissi derecesinin diğer motivasyon unsurları arasında görece düşük seviyede olduğu görülmektedir. Bu durum, çalışılan kurumun başarısını kendi başarısıyla özdeşleştirme düzeyi ile yapılan işi anlamlı bulma düzeyinin oransal yükseklikleri ile birlikte değerlendirildiğinde, bazı çalışanların yürüttükleri iş bakımından motivasyonların olumsuz etkileyen bir "monotonluk hissi" içerisinde olabileceklerini düşündürebilir.

Kamu personelinin yürüttükleri görevlere ilişkin motivasyon düzeylerinin yüksek olması, kamu hizmetlerin vatandaşa etkin ve etkili sunulması için oldukça önemlidir. Dinin insan hayatı içerisindeki yeri ve önemi düşünüldüğünde, insan hayatının önemli bir parçasını oluşturan çalışma sürecine etki etmemesi elbette mümkün değildir. Bununla birlikte kamu hizmetlerinin nitelikleri ve önemi dikkate alındığında, söz konusu etkinin derecesi ve yönü de oldukça önemlidir. Gerek Türkiye'de en yaygin din durumunda olan Müslümanlığın ve gerekse diğer din ve inanışların, kamu hizmetlerinin yürütülmesini ilgilendiren birçok ortak hükmü bulunduğu bilinmektedir. Adaletli davranmak, tarafsız olmak, devlet malına zarar vermemek, sorumlu olunan işi en iyi biçimde yapmak, rüşvet yememek, yolsuzluk yapmamak, vatandaşın hakkını gözetmek gibi birçok husus bu hükümlerden bazılarıdır.

Bu çalışmada söz konusu hükümler doğrultusunda, pozitif etki edeceği varsayıldığı için dindarlık seviyesi ile kamu hizmeti görevine yönelik çalışma gayreti ve bilinci arasındaki ilişkiyi ölçmeye yönelik anket uygulaması 
yürütülmüştür. Anket sonucunda, dindarlık ile görev motivasyonu arasında pozitif bir ilişki olduğu ancak bu ilişkinin gücünün, beklenen düzeyin oldukça altında olduğu görülmüştür.

Dindarlık düzeyinin, çalışanları manevi olarak mutlaka etkilemekte olduğu ancak tek başına görev motivasyonunu sağlamayı veya sürdürmeyi sağlamak için yetersiz kaldığı görülmektedir. Ancak burada eksiklik dinin kendisinde değil, uygulayıcı durumundaki kişilerde bulunabilir. Çünkü yukarıda belirtildiği gibi din kuralları içerisinde çalışma hayatına yön veren birçok hüküm bulunmaktadır. Bu durum, din kurallarının bilinmesine rağmen hayata uygulama konusunda zayıf kalınması ve dinin öğrenilerek değil, gözlemlenip kabullenilerek dogmatik kalıplarla yaşatılması gibi nedenlerle ortaya çıkmış olabilir. Ancak nedeni her ne olursa olsun, görevi yerine getirmeye yönlendirme bakımından zayıf bir etkileyici durumunda olduğu görülen dindarlığın, görev motivasyonunun sağlanmasının yanında, memurluğa alım, terfi, tayin, görevde yükselme gibi yönetsel kararlarda "yeter şart/ölçüt" olarak düşünülmesinin sakınca oluşturabileceği söylenebilir.

Kamu hizmetlerinin etkinliğinin artırılmasına görev motivasyonunun artırılması bakımından destek olmayı amaçlayan çalışmanın sadece Nevşehir ili merkez ilçesinde yürütülmüş olması kısıtlılık oluşturmaktadır. Bu nedenle çalışmanın gerek coğrafi olarak daha kapsamlı gerekse farklı din mensubu kamu çalışanları üzerinde yürütülmesinin dindarlık düzeyi ile görev motivasyonu düzeyi ilişkisi açısından daha belirleyici sonuçlar ortaya çıarabileceği düşünülmektedir. 


\section{EXTENDED ABSTRACT}

\section{An Analysis On Relationship Between Stated Piety Level And Task Motivation Of Public Personnel}

Serdar Vural uygun

Nevşehir HBV University

A modern public administration mentality requires that public services are conducted efficiently, effectively and as focused on citizens. It is clear that in order for this requirement to be fulfilled, one of the essential conditions will be that the civil servants who provide public services to citizens possess the qualities that have been established in the legislation to be able to conduct the service, they have awareness and are motivated for the task. If the civil servants have high motivation, they will ensure that the service that they provide is conducted much more efficiently and effectively. If the theories and studies relating to procurement of job motivations of employees are examined, it becomes evident that the main and common determinant on this matter is the psychological satisfaction level of the employee no matter which method is applied.

It may be stated that motivation is directly related to the framework of faith of the employee when this fact is taken into consideration. It is considered that the condition and level of faith of the employee meaning that level of piety is one of the principal effectors of the shaping of the personal life both in practice and spiritually. Since working life constitutes one of the most significant parts of the personal life, to examine the impact that the level of piety will make on the working performance, willingness, effort and energy; thus his motivation has been deemed significant.

As a result of the public administration literature scanning that has been done, no study in which the said two variables are examined jointly and separately has been found. As such, it is considered that examining the level and dimension of impact that piety as a fact which is frequently discussed as a part of the conjuncture on the level of motivation of the civil servants and in connection, the implementation of public services may be a contribution to the studies on efficiency of public administration as well as motivation. 
In the first section of the study, the concepts religion and piety have been defined as a part of the effort; on the other hand, in the second section, the fact motivation and studies on that topic have been examined. In addition, in the third section of the study, the outcomes of the field research that was conducted to establish the presence, level and dimension of the relationship between the level of piety and task motivation that were analyzed using SPSS 18.0 programme have been presented. Finally, the last section includes the general assessment of the topic.

The research was conducted on 291 staff members in total that officiate in the Local Health Authority, Provincial Directorate of Youth and Sports, Nevşehir Municipality and Provincial Gendarmerie Command that are located in Nevşehir city center and that render public service in different areas of activity so as to establish the condition and level of impact of the level of piety of civil servants on their task and working motivation. Survey method was made use of in the research. The survey that was arranged was put to use with a face to face meeting with 291 staff members who accepted to give response to the survey out of 411 permanent civil servant members who officiate in the given institutions. The application rate for the sample that was chosen for the survey was equal to $70,8 \%$ and then assessment phase began.

The survey that was arranged for the research consists of three sections. The first section was arranged to identify the general particulars of the participants and consisted of 2 questions. The questions that took place in this section were restricted with two very general questions with the purpose that the participants of the survey could give response to the questions on a sensitive matter like piety more realistically. The second section consists of 10 questions to establish the task and working motivation level of the employees of the institution; on the other hand, the third of 18 questions to determine the level of piety of the employee as based on a likert scale of 5 .

The scales that were arranged by Brown (1962), Faulkner and DeJong (1966), King and Hunt (1969), Mutlu (1989), Uysal (1995), Coştu (2009) and Seyhan (2015) to measure the level of piety, religious orientation and religious awareness were examined and "a survey on the level of piety" was composed after getting revised in line with the work item and then, the scales that were arranged by Allen and Meyer (1990), İncir (1990), Kuvaas (2006) as well 
as Batmaz and Gürer (2016) to establish the level of motivation of their employees were examined and "a survey on the level of task motivation" was composed after getting revised.

As a result of assessment of the survey data; according to the outcome of the correlation ( $\mathrm{r}$ ) test, it was established that there is association between the level of piety and the level of task motivation as measured that is directly proportional and that is equal to "197". This level indicates a statistically "low level" relationship between the variables that were compared (Köklü vd., 2006). As based on this, the change in the level of piety of the staff member may indicate a change in the task motivation by a rate of $19,7 \%$.

As a result, it may be stated when the data that were obtained as a result of the survey are assessed together with the statistical test outcomes $(\mathrm{p}=, 001$; $r=0,197)$ that there is a low level of significant relationship in the positive direction by $19,7 \%$ between the level of piety and level of task motivation of the corporate staff members that were measured. As such, the research hypothesis stated in the form of " $\mathrm{H}=\mathrm{As}$ the level of piety of the corporate staff members increases, the level of task motivation increases too." has been accepted.

The fact that the civil servants possess a high motivation level in relation to the tasks which they conduct is pretty significant for efficient and effective procurement of public services to the citizens. When the place and significance of religion in human life is considered, it is bound to have an impact on the working life which constitutes an important part of human life. Additionally, when the qualities and significance of public services are taken into consideration, the degree and dimension of the given impact is pretty significant. It is well-known that both Islam which is the most common religion in Turkey and other religions and faiths possess many common rules that concern the implementation of public services. Many issues including acting justly, being unbiased, not giving damage to the government property, doing one's task in the best possible way, not accepting bribes, not getting involved in corruption and observing the rights of citizens are some of the given rules.

In this study, in line with the given provisions, a survey practice was adopted with the purpose of measurement of the relationship between the level of piety and work effort and awareness relating to public service with the assumption that it will create a positive impact. As a result of the survey, it became evident that there is a positive relationship between piety and task 
motivation; however, the power of that relationship is pretty below the expected level.

It is evident that the level of piety absolutely has a spiritual impact on the employees; however, it remains inadequate to provide or continue the task motivation on its own. However, what lacks at this point may be found not with the religion itself but with the people possessing an implementer status. Because as mentioned above, among religious rules, there are many provisions that lead the working life. This situation may have emerged because of the fact that actualization of the rules of religion remains weak though being aware of them and religion is continued as based on dogmas after observing and accepting it in place of getting knowledge. It may be stated however that whatever the reason is, the fact that piety which is considered as a weak effector in terms of leading to the task fulfillment is deemed as "a sufficient condition/criterion" in administrative decisions including acceptance to public service, promotion, appointment, progress at one's job apart from procurement of task motivation may constitute a disadvantage.

The fact that the study that aimed at supporting enhancement of the efficiency of public services in terms of boost of the task motivation was conducted in the central district of Nevşehir province constitutes a limitation. Therefore, it is considered that if the study is conducted among civil servants both more diverse geographically and belonging to a multitude of religions may introduce more distinctive outcomes taking into account the relationship between the level of piety and level of task motivation.

\section{Kaynakça / References}

Ağca, V. ve Ertan, H. (2008). duygusal bağlllık içsel motivasyon ilişkisi: Antalya'da beş yıldızlı otellerde bir inceleme. A.K.Ü İ.İ.B.F. Dergisi, 10 (2), 56-71.

Akbaba, S. (2006). Eğitimde motivasyon. Kazım Karabekir Eğitim Fakültesi Dergisi, 13(3), 24-36.

Akçakaya, M. (2004). Personelin verimliliğinde motivasyonun etkisi: Keçiören belediyesi örneği. Gazi Üniversitesi İ̈BF Dergisi, 6(2), 17-29.

Allport, W. G. ve Ross, J. M. (1967). Personal religious orientation and prejudice. Journal for the Scientific Study of Religion, 5(4), 432-443.

Ayverdi, İ. (2005). Misalli büyük Türkçe sözlük. İstanbul: Kubbealtı Neşriyat 
Barutçu, S. ve Sezgin, S., (2012). Satış yönetimi sürecinde motivasyon araçları ve etki düzeyleri: Tıbbi satış temsilcileri üzerine bir araştırma. Uluslararası Alanya İşletme Fakültesi Dergisi, 4(2), 33-44.

Başaran, İ. E. (2008). Örgütsel davranış. Ankara: Ekinoks Yayın.

Batmaz, N.Y. ve Gürer, A., (2016). Dönüştürücü liderliğin çalışanların içsel motivasyonu üzerindeki etkisi: Yerel yönetimlerde karşılaştırmalı bir araştırma. Süleyman Demirel Üniversitesi İktisadi ve İdari Bilimler Fakültesi Dergisi, 21(2), 48-60.

Baysal, A. ve Tekarslan, E. (1998). Davranış bilimleri. İstanbul: İstanbul Üniversitesi İşletme Fakültesi Yayıncllık.

Bentley, T. (2000). Takımınızın yeteneklerini geliştirmede insanları motive etme. İstanbul: Hayat Yayınları.

Berkman, Ü., Can, H. ve Yüksel, Ö. (2007).Yönetim ve organizasyon. Ankara: Nobel Yayın Dağıtım.

Ceylan, A. ve Anbar, A. (2014). Modern işletmecilik. Bursa: Ekin Yayınevi.

Chen, G. ve Mathieu, J. E. (2008). Goal orientation dispositions and performance trajectories: the roles of supplementary and complementary situational inducements. Organizational Behavior and Human Decision Processes, 25(4), 106-118.

Cihangiroğlu, N. ve Uzuntarla Y. (2015). Mesleki özendiricilerin örgütsel bağlılık düzeyleri ile ilişkisi. Yönetim ve Ekonomi Araştırmaları Dergisi, 13(2), 84-95.

Coştu, Y. (2009). Dine normatif ve popüler yaklaşım “Bir Dinî Yönelim Ölçeği denemesi". Hitit Üniversitesi İlahiyat Fakültesi Dergisi, 8(15), 119-139.

Çalışkan, İ. (2002). Kur'an'da din kavramı. Ankara: Ankara Okulu Yayınları.

Dillon, M. (2003). Handbook of the Sociology of Religion. Cambridge: Cambridge University Press.

Eren, E. (2015). Örgütsel davranış ve yönetim psikolojisi. İstanbul: Beta Yayın.

Ergül, H. F. (2005). Motiasyon ve motivasyon teknikleri. Elektronik Sosyal Bilimler Dergisi, 4(14), 68.

Fındıkçı, İ. (2009). İnsan kaynakları yönetimi (7. Baskı). İstanbul: Alfa Yayınları. Fauklner, E. J. ve De Jong, F. G. (1966). Religiosity in 5-D: An empirical analysis. Social Forces, 45(2), 246-254.

Grant, A. M., Nurmohamed, S., Ashford, S. J. ve Dekas, K. (2011). The performance implications of ambivalent initiative: The interplay of autonomous and controlled motivations. Organizational Behavior and Human Decision Processes, 14(8), 116-126. 
Gröpel, P. ve Kehr, H. M. (2014). Motivation and self-control: implicit motives moderate the exertion of self-control in motive-related tasks. Journal of Personality, 82(6), 67-81.

Günay, Ü. (2002). Din sosyolojisi. İstanbul: İnsan Yayınları.

Gündüz, Ş. (1998). Din ve inanç sözlü̆̆̈̈. Ankara: Vadi Yayınları.

Hökelekli, H. (2010). Din psikolojisine giriş. İstanbul: Dem Yayınları.

Johnstone, R. L. (1992). Religion in society: a sociology of religion. New Jersey: Prentice Hall.

Kanfer, R. ve Chen, G. (2016). Motivation in organizational behavior: history, advances and prospects. Organizational Behavior and Human Decision Processes, 7(4), 136-148.

Katı, M. ve Düşükcan, M. (2017). Performansla ilişkili motivasyon araçlarının kişisel özelliklere göre farklılı̆̆ını belirlemeye yönelik bir araştırma. Social Sciences (NWSASOS), 12(1), 1-24.

King, B. M. ve Hunt, A. R. (1969). Measuring the religious variable: Amended findings. Journal for the Scientific Study of Religion, 8(2), 321-333.

Koçel, T. (2013). İşletme yöneticiliğii. İstanbul: Beta Yayın.

Köklü, N., Büyüköztürk Ş. ve Bökeoğlu, Ö. Ç., (2006). Sosyal bilimler için istatistik. Ankara: Pegem Yayıncılık.

Kurt, A. (2009). Dindarlığ1 etkileyen faktörler. Uludă̆ Üniversitesi İlâhiyat Fakültesi Dergisi, 18(2), 1-26.

Latham, G. P. ve Locke, E. A. (1992). Self-regulation through goal setting. Organizational Behavior and Human Decision Processes, 17, 50-58.

Mutlu, K. (1989). Bir dindarlik ölçeği: Sosyoloji'de yöntem üzerine bir tartışma. İslami Araştırmalar, 3(4), 194-199.

Newstrom, J.W. ve Davis, K. (2002). Organizational behavior. McGraw-Hill Com.

Ölçer, F. (2005). Departmanlı mağazalarda motivasyon üzerine bir araştırma. Erciyes Üniversitesi İktisadi ve İdari Bilimler Fakültesi Dergisi, 10(3), 25-36.

Özdaşlı, K.; Akman, H., (2012). İçsel ve dışsal motivasyonda cinsiyet ve örgütsel statü farklılaşması: Türk Telekomünikasyon A.Ş. çalışanları üzerinde bir araştırma. Süleyman Demirel Üniversitesi Vizyoner Dergisi, 4(7), 13-25.

Rawolle, M., Wallis, M. S., Badham, R. ve Kehr, H. M. (2016). No fit, no fun: the effect of motive incongruence on job burnout and the mediating role of intrinsic motivation. Personality and Individual Differences, 8(2), 64-72.

Seyhan, Y. B. (2015). Dinî şuur ölçeği:Geçerlilik ve güvenilirlik çalışması. Ekev Akademi Dergisi, 19(61), 399-413. 
Sönmez, Ö. (2016). Dindarlığın ölçülebilirliği üzerine geliştirilen dindarlık ölçekleri. SEFAD, 36(5), 557-578.

Spilka, B. Ve Hood, W. R. (1985). The psychology of religion: An empirical approach. New Jersey: Prentice-Hall Inc.

Subaşı, N. (2014). Din sosyolojisi, İstanbul: Dem Yayınları.

Şenel, B., Şenel, M. ve Gümüştekin, G.E. (2012). Banka çalışanlarının motivasyon düzeyleri üzerine karşılaştırmalı bir çalışma. Akademik Bakış Dergisi, 32(16), 41-52.

Şimşek, M. Ş., Akgemci, T. ve Çelik, T. (2010). Davranış bilimleri. Konya: Gazi Kitap

Pinder, C. C. (1998). Work motivation in organizational behavior. Saddle River: Prentice Hall.

Taş, K. (2006). Dindarlığın kriterleri üzerine tipolojik bir araştırma. Dindarlı̆̆ın Sosyo-Psikolojisi. (Ed. Ü. Günay ve C. Çelik), Adana: Karahan Kitabevi. Uysal, V. (1995). İslami dindarlık ölçeği üzerine bir pilot çalışma. İslami Araştirmalar Dergisi, 8(3), 263-271.

Vural, B. ve Coşkun, G. (2009). Örgüt kültürü. Ankara: Nobel Yayın Dağıtım.

\section{Kaynakça Bilgisi / Citation Information}

Uygun, S. V. (2020). Kamu personelinin belirtilmiş dindarlık düzeyleri ile görev motivasyonları ilişkisi üzerine bir inceleme. OPUS-Uluslararası Toplum Araştırmaları Dergisi, 15(21), 232-256. DOI: 10.26466/opus.617372 